\title{
Efeito de IL-33 e do meio condicionado de macrófagos na ativação de células tumorais
}

Os tumores se desenvolvem em microambientes complexos e dinâmicos. Macrófagos são componentes deste microambiente tumoral e essenciais na defesa do hospedeiro. Em resposta a fatores presentes no microambiente tumoral, estas células podem alterar seu fenótipo e função. Macrófagos com fenótipo M1 ou classicamente ativados, são células pró-inflamatórios e possuem atividade antitumoral. Macrófagos com fenótipo M2 ou alternativamente ativados aumentam a inflamação local e promovem progressão e metástase tumoral. Macrófagos com fenótipo M2 podem promover invasão e metástase das células tumorais. A interleucina 33 (IL33), tem sido correlacionada com a progressão de vários tipos de malignidades e associada com uma baixa sobrevida. O presente estudo se propôs a avaliar os efeitos de IL-33 e do meio condicionado de macrófagos na ativação de células tumorais da linhagem SCC-25 e Detroit 562. Verificamos que o meio condicionado da cultura dos macrófagos M1 diminuiu a motilidade e a proliferação das células tumorais da linhagem SCC-25, e ativou a expressão dos genes IL-33, ST2, SOX2, CHGA e EpCAM. Por outro lado, este mesmo estímulo down-modulou a expressão dos genes c-Myc, MYCN e SYP em células da linhagem SCC-25. Em relação aos efeitos do meio condicionado de macrófagos $\mathrm{M} 2$, os dados evidenciaram que este estímulo induziu o aumento da motilidade, proliferação e capacidade invasiva de células da linhagem tumoral SCC-25. Este mesmo estímulo induziu a expressão dos genes IL-33, ST2, NANOG, SOX2 e EpCAM por células da linhagem tumoral SCC-25, ao mesmo tempo que down-modulou a expressão dos genes cMyc, AURKA e SYP. Na linhagem tumoral Detroit 562, o meio condicionado da cultura de macrófagos M1 aumentou a motilidade destas células, diminuiu a taxa de proliferação, ativou a expressão dos genes ILL-3 e ST2 e down-modulou a expressão do gene c-Myc. Enquanto o meio condicionado de macrófagos M2 promoveu a diminuição da motilidade de células da linhagem Detroit 562 e down-modulou a expressão dos genes IL-33, SOX2 e c-Myc por estas células. Por outro lado, este mesmo estímulo levou a aumento da proliferação de células da linhagem Detroit 562. Ao analisarmos os efeitos da citocina IL-33, os resultados demonstraram que esta citocina induziu o aumento da proliferação, migração e invasão das células da linhagem SCC-25. Ademais, a citocina IL-33 levou a down-modulação da expressão de c-Myc. A estimulação com IL-33 aumentou significativamente a migração e proliferação da linha celular Detroit 562, e induziu diminuição significativa da expressão dos genes SOX2, c-Myc, SYP e EZH2. Nossos resultados indicam que a citocina IL-33 e o meio condicionado da cultura dos macrófagos M1 e 
M2 apresenta efeitos na motilidade, proliferação e invasão/migração de células da linhagem tumoral SCC-25 e Detroit 562. 